Available online on 15.11.2018 at http://ujpr.org
Universal Journal of Pharmaceutical Research
An International Peer Reviewed Journal
Open access to Pharmaceutical research is an open access article distributed under the terms of the Creative Commons Attribution-Non
Commercial Share Alike 4.0 License which permits unrestricted non commercial use,
provided the original work is properly cited
Volume 3, Issue 5, 2018

\title{
COMPARATIVE ANALYSIS OF THE PHYTOCHEMICAL COMPOSITIONS OF LEAF, STEM-BARK AND ROOT OF AZADIRACHTA INDICA (NEEM)

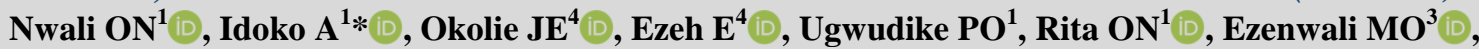

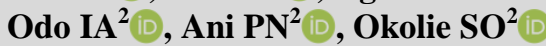 \\ ${ }^{1}$ Department of Biochemistry, Faculty of Natural Sciences, Caritas University, Amorji - Nike, P.M.B. 01784, Enugu, Nigeria. ${ }^{2}$ Department of Microbiology, Faculty of Natural Sciences, Caritas University, Amorji-Nike, P.M.B. 01784, Enugu, Nigeria. ${ }^{3}$ Department of Biochemistry, Faculty of Sciences, Enugu State University of Science and Technology, Enugu, Nigeria. ${ }^{4}$ Department of Science laboratory Technology, Osisatech Polytechnic, Enugu, Nigeria.
}

\section{ABSTRACT}

Objective: Plant chemicals abound in different parts of plants, in different compositions. Thus, the comparative screening of the leaf, stem-bark and root of Azadirachta indica becomes imperative. The presence of nine phytochemicals which include; alkaloids, flavonoids, saponins, glycosides, phenols, steroids, tannins, reducing sugars and anthraquinones, and the quantity of alkaloids, flavonoids, saponins, tannins and glycoside in the leaf, stem-bark and root of Azadirachta indica were investigated.

Methods: The plant parts were collected from a plantation grown in Okpotegu Echara, Ikwo Local Government Area of Ebonyi State, Nigeria. Plant samples were air dried at room temperature, ground into uniform powder, sieved, bottled and labeled, ready for physico - chemical analysis. Results of the investigation revealed that anthraquinones were beyond detection limits in all the plant parts tested in both ethanol and aqueous extracts.

Results: Alkaloids were not detectable in leaf, stem-bark and root samples of aqueous extract. Glycosides were not detectable in leaf sample of ethanol and aqueous extracts. Quantitatively, the phytochemical compositions of each part showed higher concentrations of Alkaloids in the leaf, stem-bark and root $(11.63 \%, 4.93 \%$ and $3.79 \%)$, compared to flavonoids $(2.19 \%, 2.72 \%$ and $0.92 \%)$, saponins $(0.70 \%, 1.12 \%$ and $0.44 \%)$, tannins $(0.33 \mathrm{mg} / 100,0.50 \mathrm{mg} / 100$ and $0.17 \mathrm{mg} / 100)$ and glycosides $(0.23 \%$, $0.27 \%$ and $0.19 \%)$, respectively.

Conclusion: Obviously, except for the higher percentage (11.63\%) of alkaloids in the leaf, the phytochemicals in the stem-bark are higher as shown by the results, which could support the reason that the bark is preferably chewed commonly together with the stem as chew stick for its germicidal and antifungal action.

Keywords: Analysis, composition, concentration, extracts, plant chemicals, screening.

Article Info: Received 8 September 2018; Revised 12 October; Accepted 4 November, Available online 15 November 2018

口if Cite this article- Nwali ON, Idoko A, Okolie JE, Ezeh E, Ugwudike PO, Rita ON, Ezenwali MO, Odo IA, Ani PN and Okolie SO. Comparative analysis of the phytochemical compositions of leaf, stem-bark and root of Azadirachta indica (neem). Universal Journal of Pharmaceutical Research 2018; 3(5): 42-46.

DOI: https://doi.org/10.22270/ujpr.v3i5.201

Address for Correspondence

Idoko A, Department of Biochemistry, Faculty of Natural Sciences, Caritas University, Amorji - Nike, P.M.B. 01784, Enugu, Nigeria. Tel: +2348032354823, E-mail: idokoalexander1@gmail.com

\section{INTRODUCTION}

Plants are nature's gift by God to man for his beneficial herbal exploits in divers applications including herbal traditional medicine, antimicrobial, antifungal, biogas production, biofertilizers and antiseptic ${ }^{1,2,3}$. Plant chemicals are referred to as phytochemicals. Several research works have identified thousands of these different plant chemicals, which were found in vegetables, fruits, beans, whole grains, nuts and seeds ${ }^{4}$. Phytochemicals are chemical compounds produced by plants, generally to help them thrive or fight against predators or pathogens. The name comes from the Greek word phyto, which means plant. Some phytochemicals have been used as traditional medicine, as poison and as nutrients ${ }^{5}$. Phytochemicals which are naturally contained in plants with known beneficial roles in the body have been classified as essential nutrients in diet, for the body's normal physiological functions ${ }^{5}$. However, Iwasaki ${ }^{6}$ Bjeldanes and Shibamoto $^{7}$, have reported the phytotoxicity and antinutrients value of some phytochemicals to humans, as aristolochic acid is carcinogenic at low doses and some interfere with nutrients absorption. Azadirachta indica species is a medium to large size evergreen tree of the tropical and sub-tropical regions of the world and is native of India. It is commonly known as Neem tree. In Nigeria, it is called Atu yabasi in Igbo, Odogoyalo in Idoma, Maina in Hausa and Dongoyaro 
in Yoruba. It belongs to the family of meliaceae and has been used as a source of drugs in many traditional African societies like Nigeria ${ }^{8}$. Researchers have reported the various uses of Neem seeds, fruits, oils, leaves, bark and root as general antiseptic, antimicrobial, and treatment of disorders (such as urinary, diarrhea, fever, bronchitis, skin disease, septic sores, hypertension, infected burns and inflammatory disease $)^{9}$. Screening of phytochemicals involves the extraction, screening and identification of bioactive substances (plant chemicals) in plants. Some of the phytochemicals were found in plants include; tannins, flavonoids, alkaloids, phenols, glycosides, carotenoids, antioxidants, steroids and saponins ${ }^{10}$. These bioactive ingredients in $A$. Indica are present in different detectable concentrations and compositions ${ }^{11}$. Phytochemicals of many plants have been assayed right from onset and in pest control, bioactive plant extracts, such as rotenone, pyrethrum and nicotine have been used $^{12}$. Interestingly, many researchers in Biochemistry, Pharmacology and Botany have their interest increased in phytochemical screening of plants for the presence of phytochemicals, for the development of medicine, pesticides and germicide functions. Feng and Isman ${ }^{13}$ doubtlessly appreciate the difficult and expensive process involved in the screening, isolation and identification of plants' secondary metabolites produced in large quantity to be commercialized. He pointed out that at least nine neem limonoids have demonstrated an ability to block insect growth, affecting a range of species that includes some of the most deadly pests of agriculture and human health $^{13}$. In a phytochemical study carried out by Harry-Asobara and Eno-Obong ${ }^{12}$, Neem leaf in comparism with the other parts of the plant gave greater percentage of alkaloid (1.38), flavonoid (0.44), and saponin (0.72). Neem seed contained greater percentage of $\mathrm{HCN}$ (13.04) and phytate (0.32) than other parts of the plants while greater percentage of tannin was observed in Neem bark (0.26) followed very closely by Neem Seed (0.24), while Neem leaf and Neem bark contained the same phenolic percentage (0.18).

\section{MATERIALS AND METHODS \\ Sample Collection and Preparation}

Fresh undamaged mature leaves were collected from several parts of the inner most canopies of the Neem tree as well as stem-barks and roots. These samples were obtained from Okpotegu Echara village in Ikwo Local Government Area of Ebonyi State. The preparation of samples collected from the field was done according to methods described by Edeoga et al., ${ }^{8}$ The leaf, stem-barks and roots collected were air dried at room temperature. The ground samples were then sieved, obtain powdered material, bottled and labeled and were ready for physic-chemical analysis.

\section{Phytochemical screening (qualitative and quantitative)}

This was performed in aqueous and ethanol extracts of A. indica leaf, stem-bark and root using standard procedure to identify the constituents as described by Harborne ${ }^{14}$; Boham and Abyazan ${ }^{15}$; Obadonic and
Ochuko $^{16}$; Van Burden and Robinson ${ }^{17}$; Singh, et al., ${ }^{18}$; Trease and Evans ${ }^{19}$.

\section{RESULTS}

The phytochemical qualitative screening (Table 1) in ethanol and aqueous leaf extracts respectively showed that, alkaloids were very deeply present $(+++)$ and deeply present $(++)$; flavonoids were very deeply present $(+++)$ and present $(+)$; saponins in frothing form were present $(+)$ in both extracts, saponins in emulsion form were very deeply present $(+++)$ and deeply present; cyanogenic glycosides were very deeply present $(+++)$ and deeply present $(++)$ while cardiac glycosides were not detectable (ND) and present $(+)$; phenols were very deeply present $(+++)$ in both extracts; steroids were not detectable (ND) in both extracts; tannins were very present $(++)$ and present $(+)$; and reducing sugars and anthraquinones were not detectable (ND) in both extracts.

Meanwhile, the quantitative analysis of leaf of $A$. indica (Table 4) reveals the phytochemical distribution in a decreasing order: Alkaloids (11.63\%), flavonoids $(2.19 \%)$, saponins $(0.70 \%)$, tannins $(0.33 \mathrm{mg} / 100)$ and glycoside $(0.23 \%)$. Table 2 shows the qualitative screening of stem-bark in ethanol and aqueous extracts respectively. Alkaloids were deeply present $(++)$ and not detectable (ND); flavonoids were very deeply present $(+++)$ in both extracts; frothing saponins were deeply present $(++)$ and very deeply present $(+++)$ while emulsion saponins were very deeply present $(+++)$ and deeply present $(++)$; cyanogenic glycosides and cardiac glycosides were very deeply present $(+++)$ in both extracts; phenols were very deeply present $(+++)$ in both extracts; steroids were deeply present $(++)$ and present $(+)$; tannins were very deeply present $(+++)$ and deeply present $(++)$; reducing sugars were present $(+)$ in ethanol extract but not detectable (ND) in aqueous extracts; while anthraquiones were not detectable (ND) in both extracts. However, Table 4 reveals the phytochemicals quantitative analysis of $A$. indica stem-bark in a decreasing order: alkaloids (4.93\%), flavonoids (2.72\%), saponins (1.12\%), tannins $(0.5 \mathrm{mg} / 100)$ and glycosides $(0.27 \%)$. Table 3 shows the qualitative screening of root in ethanol and aqueous extracts respectively. Alkaloids were deeply present (++) and not detectable (ND); flavonoids were present $(+)$ and not detectable (ND); frothing saponins were present $(+)$ and deeply present $(++)$ while emulsion saponins were deeply present $(++)$ and present $(+)$; cyanogenic glycosides were deeply present in both extracts while cardiac glycosides were present $(+)$ and deeply present $(++)$; phenols were very deeply present $(+++)$ and deeply present $(++)$; steroids were not detectable (ND) in both extracts; tannins were present $(+)$ in both extracts, while reducing sugars and anthraquinones were not detectable in both extracts. Following this (Table 4), the quantitative screening of root of $A$. indica reveals a decreasing pattern of the phytochemicals except glycosides $(0.19 \%)$ which is slightly higher than tannins $(0.17 \%)$ : alkaloids (3.79\%), flavonoids $(0.92 \%)$, saponins $(0.44 \%)$, tannins $(0.17 \mathrm{mg} / 100)$ and glycosides $(0.19 \%)$. 
Table 1: Phytochemical screening of leaf of $A$. indica in ethanol and aqueous extracts.

\begin{tabular}{lcc}
\hline Phytochemicals & $\begin{array}{c}\text { Leaf ethanol } \\
\text { extract }\end{array}$ & $\begin{array}{c}\text { Root ethanol } \\
\text { extract }\end{array}$ \\
\hline Alkaloids & +++ & ++ \\
\hline Flavonoids & +++ & + \\
\hline $\begin{array}{l}\text { Saponins } \\
\text { (a). Frothing } \\
\text { (b). Emulsion }\end{array}$ & + & + \\
\hline Glycosides & +++ & ++ \\
\hline
\end{tabular}

(a). Cyanogenic

(b). Cardiac

ND $\quad+$

\begin{tabular}{llc}
\hline Phenols & +++ & +++ \\
\hline Steroids & ND & ND \\
\hline Tannins & ++ & + \\
\hline Reducing Sugars & ND & ND \\
\hline Anthraquinones & ND & ND
\end{tabular}

Very deeply present- (+++), Deeply present- (++), Present- (+), Not detectable -(ND)

Table 2: Phytochemical screening of stem-bark of $\boldsymbol{A}$. indica in ethanol and aqueous extracts.

\begin{tabular}{lcc}
\hline Phytochemicals & $\begin{array}{c}\text { Stem-bark ethanol } \\
\text { extract }\end{array}$ & $\begin{array}{c}\text { Stem-bark } \\
\text { aqueous extract }\end{array}$ \\
\hline Alkaloids & ++ & ND \\
\hline Flavonoids & +++ & +++ \\
\hline $\begin{array}{l}\text { Saponins } \\
\text { (a). Frothing }\end{array}$ & ++ & +++ \\
(b). Emulsion & +++ & ++ \\
\hline $\begin{array}{l}\text { Glycosides } \\
\text { (a). Cyanogenic }\end{array}$ & +++ & +++ \\
(b). Cardiac & +++ & +++ \\
\hline Phenols & +++ & +++ \\
\hline Steroids & ++ & + \\
\hline Tannins & +++ & ++ \\
\hline Reducing Sugars & + & ND \\
\hline Anthraquinones & ND & ND \\
\hline deeply present- (+++), Deeply present- (++), Present- (+), Not detectable -(ND)
\end{tabular}

\section{DISCUSSION}

The qualitative phytochemical analysis of $A$. Indica in this study revealed the presence of alkaloids, flavonoids, saponins, tannins, phenols and glycosides in all plant parts studied but to varying intensities while steroids, reducing sugars and anthraquinones were not detectable in leaf and root, anthraquinones were not detectable in all plant parts investigated as shown in Tables 1, 2 and 3. Mallikharjunah et al., ${ }^{20}$ reported the usefulness of preliminary qualitative test in the detection of bioactive principle that may subsequently result in drug discovery and development. Anthraquinones were not present in the leaf, stem-bark and root of A. indica, irrespective of the extract used; this was also supported by study of Muhammed et al., ${ }^{21}$, on Acacia nilotica (Thorn mimosa). Alkaloids were not detected in a study by Aiyelaagbe et al.,22, on leaves of Magnifera indica but were detected in the leaf of this present study. In a phytochemical study on the seeds of Artocarpus communis, Artocarpus heterophyllus, Calophyllum inophyllum, Garcinia kola, Garcinia mangostana, Pentaclethra macrophylla and Treculia Africana plants, it was revealed that all the plant specimens were found to contain flavonoids and reducing compounds but none of them contain phlobatanin, cardiac glycoside, combined anthraquinone, free anthraquinone, carotenoid and steroids ${ }^{23}$, but it is on the contrary to this finding. The qualitative phytochemical screening of A. Indica on leaf, stembark and root, in this investigation revealed that alkaloids, tannins, saponins, phenols, flavonoids and glycosides abound in a substantial quality that confirms the relatedness of the work carried out by Blessing et $a l .{ }^{24}$, on Jatropha species showing these phytochemicals' potentials in drug industry. A. indica contains several active ingredients which act in different ways under different circumstances. Feng et $a l .{ }^{25}$ reported that at least nine neem limonoids have demonstrated an ability to block insect growth, affecting a range of species that includes some of the most deadly pests of agriculture and human health. The absence of steroids in leaf and root, and presence in stem-bark extracts of the neem plant in this study could explain why the stem-bark is often used (chewed raw or boiled) as pharmacotherapy for production of sex hormone $^{26}$. High concentrations of plants' secondary metabolites have been reported to be responsible for many beneficial purposes to include biofertilizers and biogas production ${ }^{2}$ and also related to their rodenticidal and pesticidal properties as investigated in previous 
studies $^{1,27}$ on Jatropha curcas seeds to a variety of insect pests. This is concurrent with this study (Table 4), were the compositions of alkaloids, flavonoids, saponins, tannins and glycosides are distributed in a manner such that alkaloids were higher (11.63\%, $4.93 \%$ and $3.79 \%$ ) in leaf, stem-bark and root respectively. However, the concentrations of these secondary metabolites were seen to progressively increase in stem-bark than in leaf and root. It has been reported that flavonoids are one of the most popular secondary metabolites possessing a variety of biological activities at nontoxic concentrations ${ }^{28}$.

Table 3: Phytochemical screening of root of $A$. indica in ethanol and aqueous extracts.

\begin{tabular}{lcc}
\hline Phytochemicals & $\begin{array}{c}\text { Root ethanol } \\
\text { extract }\end{array}$ & $\begin{array}{c}\text { Root aqueous } \\
\text { extract }\end{array}$ \\
\hline Alkaloids & ++ & ND \\
\hline Flavonoids & + & ND \\
\hline Saponins & + & ++
\end{tabular}

(a). Frothing

(b). Emulsion

Glycosides

$+$

(a). Cyanogenic

(b). Cardiac

Phenols

$\begin{array}{lcc}+++ & ++ \\ \text { Steroids } & \text { ND } & \text { ND }\end{array}$

\begin{tabular}{lcc} 
Tannins & + & + \\
\hline
\end{tabular}

Reducing

ND

ND

Sugars

Anthraquinones

ND
ND

$\mathrm{ND}=$ Not detected $;+=$ present $+++=$ deeply present and $+++=$ very deeply present.

Table 4: Quantitative phytochemical screening of $A$. indica.

\begin{tabular}{lllll}
\hline S.N. & Phytochemicals & Leaf & Steam-bark & Root \\
\hline 1 & Alkaloids & $11.63 \%$ & $4.93 \%$ & $3.79 \%$ \\
2 & Flavonoids & $2.19 \%$ & $2.72 \%$ & $0.92 \%$ \\
3 & Saponins & $0.70 \%$ & $1.12 \%$ & $0.44 \%$ \\
4 & Tannins & $0.33 \mathrm{mg} / 100$ & $0.50 \mathrm{mg} / 100$ & $0.17 \mathrm{mg} / 100$ \\
5 & Glycosides & $0.23 \%$ & $0.27 \%$ & $0.19 \%$ \\
\hline
\end{tabular}

The secondary metabolites $A$. indica investigated in this study, together with those of other plants have been severally reported to show curative activity against diverse pathogens, used traditionally as analgesic, antimicrobial and soothing herbs ${ }^{29,30,31}$, with dietary flavonoids been known to partake in cancer prevention $^{32}$. Saponins and tannins have been reported by Addae-Mensah ${ }^{33}$ for their medicinal importance as part of the component for traditional medicine (herbal) preparations for the management of various common ailments. The presence and quantity of saponins, flavonoids and phenols in the leaf, stem-bark and root of Neem (A. indica) in this study could be that they contain antioxidants, anticancer and antiinflammatory activities, as reported by Oskoueian et al., ${ }^{34}$ in the root and latex extracts of Jatropha curcas.

\section{CONCLUSION}

The qualitative and quantitative screening of the investigated phytochemicals in this work, using $A$. indica (leaf, stem-bark and root) revealed that these secondary metabolites in plants occur in different qualities and quantities. Their usefulness to pharmaceutical and other chemical industries for the production of drugs for malaria, hypertension, cancer, antidotes for many poisons, birds and insects repellant and treatment of skin infection, have been more in the traditional or herbal form. More technologies should be developed for the isolation of these secondary metabolites for their pharmaceutical applications.

\section{AUTHOR'S CONTRIBUTION}

The manuscript was carried out, written, and approved in collaboration with all authors.

\section{ACKNOWLEDGEMENTS}

The authors extend their thanks and appreciation to the Caritas University, Enugu, Nigeria to provide necessary facilities for this work.

\section{CONFLICT OF INTEREST}

Authors have declared that no conflict of interest is associated with this work.

\section{REFERENCES}

1. Faruq, Adul-Malik UZ, YU, Dabai 2004. Antibacterial activity of crude anthraquinone extract of Senna italic leaves. Biosci Res Comm 2004; 16: 7-13. https://doi.org/10.1076/phbi.39.6.408.5880

2. Ubwa ST, Asemave K, Oshido B, Idoko A. Preparation of Biogas from Plants and animal Waste. Int J Science Tech 2013; 6 (2): 480-485.

3. Sofowra A. Medicinal Plants and traditional Medicine in Africa, Spectrum Books Ltd., Ibadan, Nigeria 1993; 191289. https://doi.org/10.4236/as.2018.91012

4. Akenga T, Orech FO, Ochora J, Friis H, Aagaard H. Potential Toxicity of some Traditional Leafy Vegetable consumed in Nyang 'oma Division, Western Kenya, African J Food Nutri Sci 2005; 5(9): 1-30.

5. Molyneux RJ, Lee ST, Gardner DR, Panter KE James LF. Phytochemicals: the good, the bad and the ugly. Phytochemistry 2007; 68:2973-2985.

https://doi.org/10.1016/j.phytochem.2007.09.004 
6. Iwasaki S. Natural organic compounds that affect microtubule functions. J Pharm Soc Japan 1998; 118(4): 112-126.https://doi.org/10.1248/yakushi1947.120.10_875

7. Bjeldanes L, Shibamoto T. 2009. Introduction to food toxicology, $2^{\text {nd }}$ ed, Burlngton; Elsevier 2009; 124: ISBN:9780080921532.

8. Edoega HO, Okwu DE Mbaebic BO. Phytochemical Constituents of Some Nigeria Medicinal Plants. African J Biotechn 2005; 4(7): 685-688. https://doi.org/10.5897/AJB2005.000-3127

9. Guerra MP, Nodari RO, DosReis MS, Schmidt W. Cieniae Cultura. J Brazilian Association Advance Science 1998; 50: 408-415. https://doi.org/10.22270/ujpr.v3i5.201

10. Marcia TP, Fosquiera EC, Esmerino LA Santos EB, Farago PVFA, Santos FA, Groppo FC. Phytochemical Screening, antioxidant, and antimicrobial activities of the crude leaves extract from Lipomoea batatas (L) Lam. Pharmacog Magaz 2011; 7(26): 165-170. https://doi.org/10.1002/fsn3.268

11. Hoda SKA, Hossan MA. Studies on total phenolics, total flavonoids and antimicrobial activity from the leaves crude extracts of neem traditionally used for the treatment of cough and nausea, Bei-Suef University $\mathbf{J}$ Basic App Sci 2015:4(2): 93-98.

https://doi.org/10.1016/j.bjbas.2015.05.00

12. Harry-Asobara JL, Eno-Obong SO. Comparative Study of the Phytochemical Properties of Jatropha curcas and Azadirachta indica Plant Extracts. J Pois Med Plants Res 2014: 2(2): 020-024.

13. Feng R, Isman MB. Selection for resistance to azadirachtin in the green peach aphid, Myzus persicae, Cell. Mol. Life Sci 1995:51:831-833. https://doi.org/10.1007/BF01922438

14. Harborne JB. Phytochemical Methods, London. Chapman and Hall, Ltd.; 1973: 49-188. https://doi.org/10.1007/978-94-009-5570-7

15. Boham BA, kocipai-Abyazam R. Flavonoids and condensed tannins from leaves of Hawaiian Vaccinium Vaticulatum and V. calycynium. Pacific Science 1994: 48: 458-463

16. Obdoni BO, Ochuko PO. Phytochemical studies and comparative efficacy of the crude extract of some homostatic plants in Edo and Delta state of Nigeria. Global J Pure and Applied Science 2001:8b:203 - 208 https://doi.org/10.4314/gjpas.v8i2.16033

17. Van Burden JP, Robinson WB. Formation of Complexes between protein and tannic acid. J Agri Food Chem 1969: 1:772-777. https://doi.org/10.1021/jf60164a003

18. Singh DP, Singh A, Gupta S, Solanki E, Sharma RN. Qualitative estimation of the presence of bioactive compound in Centella asiatica: An important medicinal plant. Int J Life Sci Med Sci 2012: 2:5-7 https://doi.org/10.5963/LSMR0201002

19. Trease GE, Evans WC 1989. Pharmacognosy, $11^{\text {th }}$ edition Bailliere Tindall; 1989: London 45-50. https://doi.org/10.4236/ojce.2016.62025

20. Mallikharjunah PB, Rajanna LB, Seetharam YN Sharanabasappa GK. Phytochemical studies of Strychnos potatorum L. f.-A medicinal plant. E J Chem 2007: 4: 510-518. https://doi.org/10.1155/2007/687859

21. Mohammed SA, Sanni S, Ismail AM, Kyari AS, Abdullahi S, Amina I. Preliminary phytochemical and elemental analysis of aqueous and fractionated pod extracts of Acacia nilotica (Thorn mimosa). Vetinary Res Forum 2014: 5(2): 95-100. PMID: 25568701

22. Aiyelaagbe OO, Paul MO. Phytochemical screening for active compounds in Mangifera indica leaves from Ibadan, Oyo State. Plant Sci Res 2009: 2: 11-13. https://doi.org/10.1016/j.jksus.2015.02.003

23. Ajayi IA, Ajibade O, Oderinde RA. Preliminary phytochemical analysis of some plant seeds. Research $\mathbf{J}$ Chem Sci 2011:1(3): 58 - 62 .

24. Blessing A, Agbawa LO, Okoli BE. Comparative Phytochemical Screening of Jatropha L. species in Niger Delta. Research J Phytohem 2011: 1 -8. https://doi.org/10.3923/rjphyto.2011.107.114

25. Feng R, Isman MB. Selection for resistance to azadirachtin in the green peach aphid, Myzus persicae. Cell Mol Life Sci 1995; 51:831-833. https://doi.org/10.1007/BF01922438

26. Edeoga HO, Okwu DE, Mbaebie BO. Afr J Biotech 2005; 4: 685-688. https://doi.org/10.5897/AJB

27. Sherchan DP, Thapa YB, Khadka JT, Tiwari TP 1989. Effect of green manure on rice production. Pakhribas Agric 1989; 2: 12-15. https://doi.org/10.1016/j.still.2019.104499

28. Henning R. Fachlicher Zwischenbericht zum Projekt: Produktion und Nutzung von Pflanzenöl als Kraftstoff PN, Projet Pourghère DNHE -GTZ, Bamako, Mali. 1994; 44-49. https://doi.org/10.22270/ujpr.v3i5.201

29. Irshad AMI, Goel HC, Rizvi MMA. Phytochemical screening and high performance TLC analysis of some cucurbits. Res J Phytochem 2010: 4: 242-247. https://doi.org/10.3923/rjphyto.2010.242.247

30. Hassan MM, Oyewale AO, Amupitan JO, Abdullahi MS, Okonkwo B. Preliminary phytochemical and antibacterial investigation of crude extracts of the root bark of Detarium microcapum. J Chem Soc Nig 2004: 29: 26-29.

31. Singh A, Duggal S, Suttee A. Acanthus ilicifolius linn.lesser known medicinal plants with significant pharmacological activities. Int J Phytomed 2009; 1: 1-3.

32. Ren W, Oiao Z, Wang H, Zhu L, Zhang L. Flavonoids: Promising anticancer agents. Med Res Rev 2003; 23: 519. https://doi.org/10.1002/med.10033

33. Addae-Mensah I. Towards a rational scientific basis for herbal medicine- A phytochemist's two decades contribution. An inaugural lecture delivered at the University of Ghana, Legon: Ghana Universities Press, Accra, 1992: 63 .

34. Oskoueian E, Abdullah N, Saad WZ, Omar AR, Ahmad S, Kuan WB, Zolkifli NA, Ho YW. Antioxidant, antiinflammatory and anticancer activities of methanolic extracts from Jatropha curcas Linn. J Med Plants Res 2011; 5: 49-57. https://doi.org/10.1016/j.jep.2006.10.021 